\title{
The Expansion of University Education and Students High Results
}

\author{
Ferit Hysa \\ Doctoral Student at UET \\ ferithysa@gmail.com
}

\section{Doi:10.5901/jesr.2014.v4n3p157}

\begin{abstract}
The expansion of the university education is now a reality of Albanian society. The quality of this expansion is far from what is required by academic staff and what is expected from the society. Regarding school leadership, it is seen to be of great interest during the first years of the twenty-first century, due to the fact that it is widely believed that leadership qualities bring about significant change in schools and student's' results.(Bush, 2009). In order to have a more effective and fair education the current system of higher education requires further improvement. It should satisfy the increase of student interest in achieving high scores and decide the right balance between the student's' scores and the financial support to attend the college. The motivation of students in achieving high scores should start from high school and should be followed by their right to choose for themselves university education based on their university grant won according to the ranking of their ' $A$ ' level results. Successful completion of 'A' levels is followed by the amount of the winning grant by the candidate and the candidate decides where he/she will use it. This motivates the high school students in achieving high scores and the students themselves are oriented according to the standards, quality of service and the reputation that the university offers. The universities are more competitive and their staff will be more motivated to offer their best to the students. The society would benefit people of better quality, the proper elite, as a result of versatile work by all the intellectual staff.
\end{abstract}

Keywords: high scores, grant, financial support, motivation, 'A' level candidate, educational system, school leadership.

\section{Introduction}

The expansion of the university education is now a reality in Albanian society today. $90 \%$ of those attending high schools continue with university studies is now a reality. Confronting this reality is a challenge that requires special attention and dedication from the university counties as well as a special and a very important support from the Government.

Expansion is an overall global trend, where the number of students, according to a UNESCO report has quadrupled in the past 25 years (the world had about 50 million students in 1990, today there are close to 200 million; though the population has increased by only 1 billion). (Çili, 2013)

\section{The Expansion of High School is a Positive Phenomenon}

Going to university brings civilization and emancipation to the society. Students benefit from a multilateral development and not just knowledge about a particular profession while studying in college. Let us list some of the advantages of attending college.

- Students acquire new contemporaneous knowledge which will apply to them later in life and allow them to feel equal to their peers everywhere.

- While in college the students develop their personality and enlarge their friendships. They also become more sociable and worthy able to be integrated into the civilized world.

- In college they become professionally equipped, ready to build their future.

- While in college they identify their values and opportunities for their intellectual and professional development.

- While in college the students acquire the habit of lifelong learning, a method which has been applied in the United Kingdom for years. education

The expansion of university education cannot be done without an increased effectiveness of the high school 


\section{The Increased Effectiveness in High Schools}

The expansion of university education cannot be perceived without achieving high credits in high school.

This is a prerequisite for having a qualitative and effective education. The knowledge that students acquire in high schools must enlarge. This requires that education reform should continue especially in:

- Improving of the school's curriculum where a special focus should be on the knowledge and the skills that students require in order to pursue higher education. Everything should be done to gain this knowledge and ability so that every student might have the possibility to attend college. Programmed courses of learning and relearning the knowledge to facilitate this process creates the environment for a certain attendance of higher education.

- Making the education less difficult by defining the core subjects alone as the obligatory condition for passing from one grade to the next one; while the obligatory subject choice may only add credits to go to college, to have a wider choice or to win a scholarship to have greater financial support.

- Ensuring a teaching environment in accordance with the students age characteristics as well as current information technology. The traditional ways of teaching do not lead to the participation of every student and the communication with the teachers is not interactive.

- Providing information technology to the students in every school during classes. Much class teaching may, and should be, substituted with online teaching. Foreign language, another need to be met, leads to a greater number of students that would attend higher education and it cannot be taught without the aid of information technology. Of course, this cannot easily be done in small schools but it should be a priority when coming to schools with large numbers of students (e.g., over 500 high school students)

- The stimulation of the best students and giving them grades according to their level of acquired knowledge would make students more zealous to study harder, especially the less interested ones.

- Teaching staffs, parents and the local community have lots of reserves. The Improvement of school management would bring much result in our schools.

School Leadership leads to the high- score results of students and thus a greater number of them could go to college.

The increased number of the students that go to university requires an effective management and a proper knowledge. In our schools until now the leading has been done from unqualified school leaders and with an absolute centralization. Before ' 90 the school management was highly politicized and tradition has continued but in the other sides and after 1990.

New education law for high schools has a lot of improvements regarding school decentralization and depoliticization. There is an increased awareness on the behalf of the school leaders and also the self-management and leading competencies of the schools are increased. In Albania there are about 2000 elementary and high schools with about 40000 teachers. These teachers teach more than 90,000 students and they must cooperate with approximately the same number of families and other interested parties that influence a good learning process. Is this educational management industry being considered and, how much if so?

Seeing that such an increased number of high schools students is the foundation that would lead to a greater number of students going to university so the direction of the school should be based on the best theories and practices of management and leadership in education.

Occasions of specific preparation in connection with school is connected with evidence that a

Professional leadership is a vital element in improving the education and results of the student (Bush, 2009).

In order to have leaders with the required scientific and academic qualification it is required:

- Universities should offer Master and Master of Science programmes to provide contemporary education regarding school management. So far two for each (2010-2011) of scientific and professional masters programmes are being offered. This is insufficient compared to the school requirements of today

- Consolidation of the school leadership training curricula. Anglo-Saxon School provides good experience regarding leadership training programmes. For about 20 years they have been developing academic curricula for vocational school leaders at master level.

- Training of the school leaders through accredited programmes. The acquiring of skills cannot be fulfilled without a series of trainings. The gain of application skills is as important as that of academic knowledge.

All these requirements enable our school to respond to the student's demands. How will we motivate and value better the pupils' knowledge for the students to go to university? 
Below we raise some questions such as:

' $A$ ' level attainment; how college education is earned; the right of knowledge of assessment; the right to choose the field of study; the right to choose the university.

One of the major achievements, we all agree, is the , standard of 'A' level which in addition to eliminating corruption regarding enrolment to college, clearly defines the merit preference principle as the criterion to earn university education. With some little defect, this stands well in order to rank the students level and students to competitive in equals orders to win the high studies (University studies).

The number of students attending university is continuously increasing. This is because of the increased demand of the students to go to college but it is also in the government's goals to increase this number from year to year. This is a very powerful and important investment of the government for society (Hysa, 2011).

On the other hand this is an investment of the society itself because it is its burden to support these students and it is the task of the government to manage it in the most effective and fair way. So this process should be managed fairly and effectively. The right of the student to choose their favourite and preferred education and to earn it is almost resolved by the merit preference principle which is applied to determine the winner of the right for education. But for these rights of study to be effective and proper they must be in correct schools and universities of quality.

Regarding the quality and the standard of universities we need to thank the Ministry of Education and Science for its commitment to evaluate these universities by the ranking method made known to the public and the citizens through a clear presentation of their level, even though that UT, being the largest university, should have been involved in this process. There were many problems to the state university and to be protected in public opinion does not take part in the processing of rating. The ' $\mathrm{A}$ ' level candidate is clear regarding the quality of universities and on these bases he/ she will choose where to go.

All this investment of the society has the student in its centre . It aims to support the society to contribute so that the best may go to the best schools and that they may choose to study in those fields where the need is and, finally, to achieve a good education which will return for the good of the society. This investment is not just a goal that would come as a gift for the student but it is also a responsibility for the future of society.

We have a fully funded sector and another sector that is funded by the student. So Albanian parents pay taxes for the public dues and pay again to send children to private universities (Civici, 2012).

Here arises the difficulty with the conformity of the entire selecting process of the student's right to choose education, especially of the students with the highest credits who are deprived of the right to choose the best universities in Albania. Instead they can choose only public universities. Even though MASH itself is convinced that it is not offering the best to the student., it is not fair that the student cannot reach the levels where their skills and talents are.

It is not fair that the society which contributes to the education sector does not get the results in accordance with it. It is not fair that the good universities are not able to have the best students in them for these latter cannot pay for their education. This goes in the favour of the universities which are not so good and yet are able to recruit the best students because the latter have no other choice in which to reform and compete in a fair manner with their attainments.

What is aimed at regarding the education financial reform is that the state may guarantee equal education for all. So if we finance the offer we should finance the demand as well, that is to say, the actual student (Civici, 2012).

Therefore, the government should establish the grant of the education covering in accordance with the student payments in the case of studying in the public universities. It should also determine the quota to be covered and the expenses of the universities. It should define the universities according to their listed ranking and the student may then decide whether to go to a private or state university.

This causes the good students to be awarded fairly; the society's expenses to be converted into good results and for the society itself to get the best professionals. The universities also can reform themselves as a result of competition. The benefit is for all of us but we should know how to use it wisely. We should have an answer for the question: where can the students go?

\section{Conclusion}

The expansion of university education requires a better management and a programmed guidance for the needs of the students and the society. The increased quality of the results of high school students, the incentives of the results for choosing their desired study program and the university will enable a better performance of the work with the student. It 
also would lead to pursuing studies in accordance to their merit and an increased competition among universities, providing programs according to the needs of the students and society.

\section{References}

Baldridge, J.V., Curtis, D.V., Ecker, G. and Riley, G.L. (1978). Policy Making and Effective Leadership, San Francisco, CA: Jossey Bass. Bass,B.M., (1985). Leadership and Performance Beyond Expactions. New York. Free Press.

Beare, H., Caldwell,B.J. and Millikin, R.H. (1989). Creating an Exellent School, London: Routledge.

Blake,R.R. and Mouton,J.S. (1964). The Managerial Grid, Houston, Texas: Gulf Publishing Co.

Bottery, M.(1992). The Ethics of Educational Management, London: Cassell.

Burns,J.M. (1978). Leadership. New York: HarperCollins.

Bush, Bell,Bolam, Glatter and Ribbins. (1999). educational management. London, Paul Champman Publishing.

Bush, T. (1986). Theories of Educational Management, PCP.

Bush Tony. Education Review. Leadership development and school improvement.Vol.61. no.4, November 2009, 375-389.

Bush,T and West- Burnham J.(1994) The Principles of Educational Management. Longman Group UK Ltd

Caldwell, B.J. and Spinks,J.M. (1988). The Self Managing School, Lewes: Falmer Press.

Caldwell, B.J. and Spinks,J.M. (1992). Leading the Self-Managing School, London: Falmer Press.

Civici Ardian : Shteti të garantojë standardet, studenti të zgjedhë http://WWW.mapo.al/2012/10/10/adrian-civici-shteti-te-garantoje-standardetstudenti-te-zgjedhe/ 2012

Çili Henri. Është krijua idea se ...masivizimi i arsimit të lartë është i dëmshëm. http://www.mapo.al/2012/10/13/eshte-krijua-idea-se-masivizimi-iarsimit-te-larte-eshte-i-demshem/ 2013

Daphne Johnson. (1994).Research Methods in Educational Management.Longman Group UK Ltd

DFE, (1992). Choice and Diversity: A New framework for schools, (Cmnd 2021), London:HMSO

Fullan,M. (2001).Kuptimi i Ri i Ndryshimit ne Arsim. Tirane. Botimi Trete.

Fullan,M.G.(1991). The New Meaning of Educational Change.New York:Teachers College Press.

Gjedia,R. dhe Llambiri S., (2007).Plani afatmesem i shkollës. Tiranë.

Greenfield,T. and Ribbins, P. (1993). Greenfield on Educational Administration. London:Routledge.

Handy, C. and Aitken, R. (1986). Understanding Schools as organizations, Harmondsworth:Penguin.

Hargeaves,D. and Hopkins,D. (1991). The Empowered Schools: The management and Practice Of Development planning, London: Cassell.

Hargreaves,A. (1993). 'Contrived collegiality: the micropolitics of teacher collaboration' in Bennett, N., Crawford, M., riches, C. (Eds). Managing Change in Education: Individual and Organizational Perspectives,London: Poul Chapman.

Hughes, M., Ribbins,P. and Tomas,H. (1985). Managing Education, London: Holt.

Hysa F. Matura, Universiteti, Rankimi, dilemat e studentit. Gazeta Mapo nr 236 ,2011

Instituti i Kurrikulës dhe Trajnimit.(2008). Drejtimi i shkollës. Udhezues për drejtuesit e shkollës. Tiranë.

ISP. (2002) (3). Administrim dhe Menaxhim Arsimi. Tirane

Jones,A. (1987). Leadership for Tomorrow's Schools, Oxford: Blackwell.

Likert,R. (1967). The Human Organization: its Management and Value, New York: Mcgraw-Hill.

Livingstone, H. (1974)The University: an Organizational Analysis, Glsagow: Blackie.

Llambiri, S. (2006). Braktisja e fshehte "Nga Fundi ne Fillim" Per drejtorin e shkolles. Tirane

Maw,J. et al. (1984). Educational PIc?London Institute of Education, London: Heinemann.

March,J.G., and Simon, H.A. (1958). Organizations. New York: John Wiley.

Marland,M. (1982). 'The politics of improvement in schools'. Educational Management and Administration, 10.2,pp.119-134.

Murgatroyd,S. and Gray,H.L (1984) 'Leadership and the effective school' in Harling,P (Ed) New Directions in Educational Leadership, London: Falmer Press.

O'Neil,J.(1994) "Change Starts with individual, Fullan Contends." ASCD Update, May 1994, 36(4).

Sekaran,U. (2003) Research Methods for Business. United Kingdom.

Sergiovanni, T.J. (1984). 'Leadership and excellence in schooling'.Educational Leadership, February.

Sergiovanni, Th.J. (1996). Leadership for the Schoolhose. California.

Sergiovanni,T.J. (1995). The Principalship: A Reflective Practice Perspective.(3rd ed.) Needham Heights, Mass.:Allyn\&Bacon.

Squire, W.H. (1987). Educational Management in UK, Aldershot: Gower.

Stogdill (1969). 'personal factors associated with leadership: a survey of the literature' in Gibb,C.A. (Ed), Leadership, Harmondsworth: Pengiun.

Taylor, W. (1979). 'The head as manager' in Peters, R.S. (Ed). Role of the Head, London:Routledge \& Kegan Paul.

Theodossin, E. (1983). 'Theoretical perspectives on the management of planned educational change'. British Educational Research Journal,9,1,pp.81-90.

Tony Bush and Marianne Coleman.(2002). Leadership and Strategig Management in Education. Paul Champman Publishing Ltd, London EC2A $4 \mathrm{PU}$.

Torrington, D. and Weightman, J. (1989). The Reality of School Management. Oxford: Blackwell.

Torrington, D. and Weightman, J. and Johan,K.( 1989). Effective Management. Prentice Hall.

West,S.( 1993). Educational Values for School Leadership, London: Kogan Page

Yeomans, R. (1987). 'Leading the team, belonging to the group?' in Southworth, G. (Ed) Readings in Primary School Management, London: Falmer Press. 